\title{
PORNOGRAFIJA, STAV O UPORABI KONDOMA I UPORABA KONDOMA KOD RIJEČKIH ADOLESCENATA
}

\author{
Goran Koletić i Jasmina Mehulić
}

\author{
Odsjek za sociologiju \\ Filozofski fakultet, Sveučilište u Zagrebu \\ Ivana Lučića 3, 10000 Zagreb \\ e-mail: gkoletic@ffzg.hr
}

\begin{abstract}
Sažetak
Jednostavnost pristupa internetskoj pornografiji izazvala je zabrinutost odgojnih stručnjaka i opće javnosti zbog negativnih ucinaka pornografije na psihosocijalno i seksualno sazrijevanje adolescenata. Pretpostavljena povezanost izmedu uporabe pornografije i rizičnog seksualnog ponašanja, posebice nezaštićenog spolnog odnosa, često se nalazi u središtu pozornosti. Prema dosadašnjim istraživanjima, stav o uporabi kondoma važan je prediktor stvarne uporabe kondoma. Mecutim, razmjerno je malo studija analiziralo povezanost izmedu uporabe pornografije, stava o uporabi kondoma i uporabe kondoma medu adolescentima. Konceptualni okvir ove studije čini nedavno razvijeni model akvizicije, aktivacije i aplikacije (_AM). Cilj je ove studije analiza longitudinalne povezanosti izmedu učestalosti uporabe pornografije te stava o uporabi kondoma $i$ uporabe kondoma pri posljednjem spolnom odnosu. Podaci su prikupljeni metodom ankete $u$ dva vala među učenicimalama 14 riječkih srednjih škola od 2015. do 2018. godine ( $N=227 ; M_{\text {dob }}=17,3$; $S D=0,5)$. Kontrolirajući traženje uzbudenja i permisivne stavove o seksualnosti, provedena je višsegrupna ukrižena analiza primjenom strukturalnog modeliranja. Utvrđena je longitudinalna povezanost izmedu učestalosti uporabe pornografije i negativnijeg stava o uporabi kondoma, ali samo kod mladića. Nije utvrdena longitudinalna povezanost izmedu uporabe pornografije i uporabe kondoma. Povrh rasprave o rezultatima, zaključno se razmatraju preporuke za daljnja istraživanja i praktične implikacije. Dobiveni nalazi mogu poslužiti stručnjacima iz područja obrazovanja, medijske pismenost i javnog zdravstva, ali $i$ siroj javnosti.
\end{abstract}

Ključne riječi: pornografija, stav o uporabi kondoma, uporaba kondoma, adolescenti, longitudinalno istraživanje, strukturalno modeliranje

\section{UVOD ${ }^{1}$}

Seksualnost predstavlja jedan od ključnih aspekata psihofizičkog odrastanja adolescenata (Fortenberry, 2016). Međutim, razvoj seksualnosti u adolescenciji ujedno je obilježen određenim ugrozama i rizicima, posebice u vidu seksualnog i reproduktivnog zdravlja.

1 Rad se temelji na istraživanju koje financijski podupire Hrvatska zaklada za znanost (projekt br. 9221). 
Među rizicima, seksualne aktivnosti koje možebitno narušavaju seksualno i reproduktivno zdravlje, a time i širu psihofizičku i društvenu dobrobit pojedinaca, predstavljaju jedno od ključnih ishodišta kako društvene tako i javnozdravstvene zabrinutosti. Zbog rizičnih seksualnih ponašanja, adolescentska je dob obilježena najvećim dobno-specifičnim rizikom za spolno prenosive infekcije i najvećim dobno-specifičnim udjelom neželjenih trudnoća (Centers for Disease Control and Prevention, 2017). Nezaštićeni spolni odnosi zauzimaju središnje mjesto među rizičnim seksualnim ponašanjima. Štoviše, prema nedavnoj globalno orijentiranoj meta-analizi, nezaštićeni spolni odnosi navedeni su kao drugi vodeći rizik povezan sa zdravljem i smrtnošću u dobi između 15 i 19 godina (Mokdad i sur., 2016). Prema rezultatima istraživanja provedenom na uzorcima hrvatskih adolescenata, oko 35\% mladića i 47\% djevojaka navelo je nekorištenje kondoma pri posljednjem spolnom odnosu (Pavić Šimetin i sur., 2016). Slični, a time i jednako zabrinjavajući udjeli nekorištenja kondoma zabilježeni su i u dobi netom nakon adolescencije (Landripet i sur., 2011; Štulhofer i sur., 2009). Nadalje, stav o uporabi kondoma često se ističe kao važan prediktor stvarne uporabe kondoma ili namjere uporabe kondoma (Albarracín i sur., 2001; Sheeran i sur., 1999; Teye-Kwadjo i sur., 2017; Vasilenko i sur., 2015). Primjerice, prema rezultatima nacionalno-reprezentativnih istraživanja o rizičnom seksualnom ponašanju mladih iz 2005. i 2010. godine, negativniji stav o uporabi kondoma bio je povezan $s$ manje izglednom dosljednom uporabom kondoma $\mathrm{u}$ proteklih 12 mjeseci (Landripet i sur., 2011).

Zbog značajnih promjena na informacijsko-komunikacijskom planu, kojeg unazad dva desetljeća obilježava uvelike olakšan pristup internetu, povećana uporaba pornografije među adolescentima zauzima svoje mjesto u javnoj sferi, prvenstveno u vidu zabrinutosti zbog neželjenih i štetnih ishoda. Moguće se štetnosti uporabe pornografije tematiziraju na više razina, odnosno među tvorcima politika (Petley, 2014), roditeljima (Quadara i sur., 2017) i odgojnim stručnjacima (Rothman i sur., 2018). Pretpostavka je da zbog nedostatka životnih iskustava i kognitivnih sposobnosti potrebnih za prepoznavanje fikcijskog u pornografskom prikazu seksualnosti, adolescenti čine osjetljivu i ranjivu populaciju korisnika pornografije (Peter i Valkenburg, 2010). Mogući utjecaj pornografskih sadržaja na seksualne stavove i ponašanja adolescenta izaziva dodatnu bojazan jer usvojeni obrasci rizičnih seksualnih ponašanja tijekom adolescencije mogu utjecati na seksualno ponašanje u post-adolescenciji, time kumulativno povećavajući rizik od neželjenih zdravstvenih ishoda (Fergus i sur., 2007; Palmer i sur., 2017). Međutim, uloga pornografije u zdravstveno-seksualnoj socijalizaciji adolescenata do sada je privukla razmjerno malu pozornost znanstvene zajednice (Peter i Valkenburg, 2016).

\subsection{Konceptualni okvir rada}

U ovom se radu odnos uporabe pornografije s ponašanjem i stavovima objašnjava modelom akvizicije, aktivacije i aplikacije ( ${ }_{3}$ AM; Wright, 2011). Riječ je o teorijskom modelu kojim se tumače mehanizmi mogućeg utjecaja seksualiziranih medija na seksualnu socijalizaciju odraslih i adolescenata (Wright, 2014). Oslanjajući se na teoriju seksual- 
nih skripti (Gagnon i Simon, 2005), model pretpostavlja utjecaj, primjerice, pornografije na ponašanje ili stavove putem seksualnih skripti. Seksualne su skripte simboličke smjernice koje kroz prizmu situacijske prikladnosti i društvene normativnosti potiču određena seksualna ponašanja. Pornografski sadržaj korisniku pornografije može pružiti potpuno nove seksualne skripte (akvizicija) ili aktivirati već postojeće (aktivacija). Treća faza (aplikacija) predstavlja kognitivno-emocionalnu evaluaciju usvojenih ili aktiviranih seksualnih skripti, odnosno evaluaciju (ne)prikladnosti ili (ne)prihvatljivosti realizacije te procjenu određenog ponašanja ili stava u vidu nagrade ili kazne. Drugim riječima, aplicirana pornografska skripta adolescentima može poslužiti kao smjernica za stvarni seksualni odnos ili za formiranje stava o određenoj seksualnoj praksi. Shodno tome, konzumiranje pornografije u kojoj je uporaba kondoma rijetkost moglo bi dovesti do internalizacije takve pornografske skripte i rezultirati negativnijim stavom prema kondomima ili čak rjeđom uporabom kondoma u spolnom odnosu. Međutim, valja istaknuti da aplikacija rizičnih seksualnih skripti na razini stava ili ponašanja nije nužan ishod za sve adolescente zbog psihosocijalnih razlika između adolescenata te sadržajno-situacijskih obilježja uporabe pornografije.

\subsection{Dosadašnja istraživanja}

Prema našem saznanju, trenutno ne postoje istraživanja koje tematiziraju odnos uporabe pornografije i stava o uporabi kondoma. $S$ druge strane, empirijski uvidi o povezanosti učestalosti uporabe pornografije i stvarne uporabe kondoma među adolescentima proizlaze većinom iz presječnih istraživanja. Jedno starije američko istraživanje utvrdilo je pozitivnu povezanost između uporabe pornografije i nekorištenja kontracepcije pri posljednjem spolnom odnosu na uzorku afroameričkih djevojaka u dobi od 14 do 18 godina (Wingood i sur., 2001). Drugo američko istraživanje, također na uzorku kojeg su većinom činile djevojaka etničkog manjinskog podrijetla (12-22 godine), nije utvrdilo ciljnu povezanost (Braun-Courville i Rojas, 2009). Nadalje, nacionalno-reprezentativno istraživanje švicarskih adolescenata između 16 i 20 godina starosti utvrdilo je povezanost između učestalosti uporabe pornografije i korištenja kontracepcije pri posljednjem seksualnom odnosu, ali samo među mladićima (Luder i sur., 2011). Nedavno provedeno australsko istraživanje nije utvrdilo povezanost između uporabe pornografije i korištenja kontracepcije na uzorku sudionika/ca dobi između 15 i 29 godina (Lim i sur., 2017). Konačno, samo su dva longitudinalna istraživanja analizirala ciljnu povezanost. Koristeći dvije točke mjerenja na nacionalno-reprezentativnom uzorku nizozemskih adolescenata u dobi od 12 do 17 godina, Peter i Valkenburg (2011a) također nisu utvrdili povezanost između učestalosti uporabe pornografije i iskustva nezaštićenog seksualnog odnosa šest mjeseci kasnije. Analizirajući rizično seksualno ponašanje u osam točaka mjerenja, nedavno tajvansko istraživanje utvrdilo je negativnu povezanost između učestalosti uporabe pornografije i dosljednosti u korištenju kondoma kod sudionika/ ca na prijelazu iz adolescencije u post-adolescenciju (Lin i sur., 2020). 
Moguće uzroke nedosljednosti postojećih empirijskih uvida potrebno je sagledati kroz prizmu metodoloških i konceptualnih razlika. Uzorci istraživanja razlikuju se prema dobnom rasponu te omjeru muških i ženskih sudionika/ca. Također su primijenjene različite strategije uzorkovanja. Osim nacionalno-reprezentativnog švicarskog i nizozemskog istraživanja (Luder i sur., 2011; Peter i Valkenburg, 2011a), ostala su istraživanja temeljena na neprobabilističkim prigodnim uzorcima. Razlikuju se i operacionalizacije učestalosti uporabe pornografije kao i sama definicija pornografije. Primjerice, vremenski okvir procjene uporabe pornografije varira od posljednja 3 mjeseca, 6 mjeseci do 12 mjeseci. U konačnici, valja uzeti u obzir i razlike informacijsko-komunikacijskog konteksta u vrijeme provođenja navedenih istraživanja, što se prvenstveno odnosi na mogućnosti pristupa internetu i online pornografiji.

\subsection{Cilj i hipoteze}

Cilj je ovog istraživanja analizirati longitudinalnu povezanost između učestalosti uporabe pornografije i stava o uporabi kondoma te stvarne uporabe kondoma među adolescentima.

Temeljem dosadašnjih istraživanja i primijenjenog ${ }_{3} \mathrm{AM}$ modela, testirane su sljedeće hipoteze:

H1: Učestalija uporaba pornografije u prvoj točki mjerenja bit će pozitivno povezana s negativnijim stavom o uporabi kondoma 12 mjeseci kasnije; i

H2: Učestalija uporaba pornografije u prvoj točki mjerenja bit će negativno povezana s uporabom kondoma 12 mjeseci kasnije.

Shodno preporukama i nalazima dosadašnjih istraživanja, u središnjim je analizama kontroliran doprinos sklonosti traženju uzbuđenja i prihvaćanja permisivnih stavova o seksualnosti. Prema teoriji optimalne pobuđenosti, tražitelji uzbuđenja namjerno se izlažu podražajima većeg intenziteta kako bi postigli optimalnu pobuđenost (Carrol i sur., 1982). Traženje uzbuđenja bilo je u većem broju dosadašnjih istraživanja povezano i s učestalijom uporabom pornografije kod adolescenata (Peter i Valkenburg, 2011b), ali i sklonosti rizičnom ponašanju (Zimmer-Gembeck i Helfand, 2008), uključujući i sklonost seksualnom rizičnom ponašanju (Luder i sur., 2011). Nadalje, dosadašnja su istraživanja ukazala na pozitivnu povezanost između permisivnih seksualnih stavova i rizičnog seksualnog ponašanja (Ashenhurst i sur., 2017; Warner, 2018) te permisivnih seksualnih stavova i učestalije uporabe pornografije (Baams i sur., 2014; Leonhardt i Willoughby, 2018).

Znanstveni se doprinos očituje u nekoliko obilježja istraživanja. Prvo, većina dosadašnjih istraživanja presječnog su tipa. Longitudinalni dizajn ovog istraživanja omogućuje uvid u promjene kroz vrijeme i znatno robusnije analize u odnosu na presječna istraživanja. Drugo, istovremeno se analizira povezanost pornografije sa stavom o uporabi i stvarnom uporabom kondoma. Dosadašnja su istraživanja na uzorcima adolescenata bila primarno usmjerena na odnos pornografije i uporabe kondoma, zanemarujući komponentu stava prema uporabi kondoma. S obzirom na to da istraživanja na uzorcima odraslih ukazuju na medijacijsku ulogu stavova o seksualnosti u povezanosti između uporabe 
pornografije i seksualnog ponašanja (Wright, 2018), potrebno je rasvijetliti osnovne povezanosti uporabe pornografije sa stavom o uporabi i stvarnom uporabom kondoma među adolescentima. Temeljem dobivenih uvida i sukladno teorijsko-konceptualnom okviru utvrđuju se pretpostavke za daljnju provjeru potencijalno složenijih analitičkih modela. Treće, gotovo sva dosadašnja istraživanja provedena su u državama koje odlikuje nešto liberalnija i permisivnija seksualna socijalizacija mladih (SAD, Ujedinjeno Kraljevstvo, Australija, Švicarska). Navedene države ujedno posjeduju razvijenije sustave podučavanja medijske pismenosti i seksualne edukacije (Rothman i sur., 2018; Tarrant, 2015). S druge strane, u Hrvatskoj je prisutan tradicionalniji pristup seksualnosti, čak i naspram drugih europskih većinski katoličkih zemalja (Štulhofer i Rimac, 2009).

Dobiveni nalazi mogu poslužiti stručnjacima iz područja obrazovanja, medijske pismenost i javnog zdravstva, ali i široj javnosti gdje je već prisutna zabrinutost glede mogućih štetnih posljedica uporabe pornografije u kontekstu reproduktivnog i seksualnog zdravlja adolescenata.

\section{METODOLOGIJA}

\subsection{Sudionicile i provedba istraživanja}

Podaci za istraživanje prikupljeni su u okviru istraživačkog projekta Prospective Biopsychosocial Study of the Effects of Sexually Explicit Material on Young People's Sexual Socialization and Health kojeg financijski podupire Hrvatska zaklada za znanost (projekt br. 9221; http://probiops.ffzg.hr). Panel-uzorak činili su učenici/e drugih razreda 14 srednjih škola u gradovima Rijeci i Opatiji. U razdoblju od prosinca 2015. do ožujka 2018. godine provedeno je šest valova prikupljanja podataka, svakih 4 do 6 mjeseci. U prvom je valu (T1) prikupljeno 1.287 valjanih upitnika (raspon dobi sudionika/ca bio je od 15 do 17 godina; $M_{\text {dob }}=15,9 ; \mathrm{SD}=0,62 ; 43,9 \%$ sudionika i $56,1 \%$ sudionica), što čini $62 \%$ te generacije učenika/ca2. Broj valjanih upitnika u narednim valovima iznosio je 1.281 (T2), 1.232 (T3), 1.176 (T4), 931 (T5) i 892 (T6). Izraženiji pad broja sudionika/ca zabilježen u petom valu posljedica je završetka školovanja učenika/ca upisanih u trogodišnje školske programe.

Nakon dobivenog pristanka ravnatelja/ica, stručni suradnici/e srednjih škola pismeno su obavijestili roditelje potencijalnih sudionika/ca o ciljevima i svrsi istraživanja. Prikupljanje podataka provedeno je tijekom nastave pomoću tiskanih upitnika uz prisustvo člana istraživačkog tima. Između sudionika/ca postavljene su kartonske pregrade kako bi se osigurala privatnost prilikom ispunjavanja upitnika. Svaki je upitnik sadržavao informirani pristanak te upute za generiranje jednostavne slovno-brojčane šifre koja je služila za povezivanje upitnika kroz valove. Na kraju svakog upitnika naveden je kontakt organizacije „Hrabri telefon" u slučaju da je sudionike/ce tijekom ili nakon ispunjavanja upitnika nešto uzne-

2 Prema podacima Ureda za odgoj i obrazovanje Primorsko-goranske županije o broju učenika/ca upisanih u riječke $(\mathrm{N}=18)$ i opatijske srednje škole $(\mathrm{N}=4) 2014$. godine. 
mirilo ili zabrinulo. Istraživanje je 2. lipnja 2014. godine odobrilo Etičko povjerenstvo za znanstveno-istraživački rad Filozofskog fakulteta Sveučilišta u Zagrebu.

Analize prikazane u radu temeljene su na podacima sudionika/ca koji su sudjelovali u četvrtom i šestom valu jer je u navedenim valovima korištena mjera stava o uporabi kondoma $(\mathrm{N}=716)$. S obzirom da su pitanja o uporabi kondoma i stavu o uporabi kondoma bila namijenjena samo sudionicima/ama koji su naveli iskustvo spolnog odnosa, središnja je analiza provedena na poduzorku seksualno aktivnih sudionika/ca $\left(\mathrm{N}_{\mathrm{T} 4+\mathrm{T} 6}=227\right)$. Sociodemografska obilježja sudionika/ca s obzirom na iskustvo spolnog odnosa prikazana su u Tablici 1.

U svrhu procjene pristranosti zbog osipanja sudionika/ca kroz vrijeme provedena je višestruka logistička regresijska analiza. Zavisnom su varijablom razdvojeni sudionici/e koji su sudjelovali u oba vala od onih koji nisu. Indikator uporabe pornografije i sociodemografski indikatori (spol, dob, tip škole, tip obitelji, školski uspjeh i obrazovanje roditelja) mjereni u T1 uključeni su u regresijsku analizu kao nezavisne varijable. Rizik osipanja bio je značajno veći u muških sudionika $(A O R=1,41 ; p=0,045)$ te onih slabijeg školskog uspjeha (AOR=0,75; $\mathrm{p}<0,001$ ), ali uz malu veličinu učinka (Chen i sur., 2010).

Tablica 1. Sociodemografska obilježja sudionikalca koji su sudjelovali u četvrtom i šestom valu (N=716) sobzirom na iskustvo spolnog odnosa u oba vala

\begin{tabular}{|l|l|c|c|c|}
\hline & & $\begin{array}{c}\text { Bez iskustva } \\
\text { spolnog odnosa } \\
(\mathbf{N}=489)\end{array}$ & $\begin{array}{c}\text { S iskustvom } \\
\text { spolnog odnosa } \\
(\mathbf{N}=227)\end{array}$ & p \\
\hline \multirow{2}{*}{ Spol } & & $\mathbf{N}(\%)$ & $\mathbf{N}(\%)$ & \\
\hline \multirow{2}{*}{ Tip škole } & Muški & $188(38,4)$ & $69(30,4)$ & 0,045 \\
\cline { 2 - 5 } & Ženski & $301(61,6)$ & $158(69,6)$ & \\
\hline \multirow{2}{*}{ Tip obitelji } & Gimnazija & $202(41,3)$ & $65(28,6)$ & 0,001 \\
\cline { 2 - 5 } & Druge srednje škole & $287(58,7)$ & $162(71,4)$ & \\
\hline \multirow{2}{*}{ Obrazovanje majke } & Obitelj s oba roditelja & $367(83,8)$ & $151(74,4)$ & 0,007 \\
\cline { 2 - 5 } & Drugi tipovi obitelji & $71(16,2)$ & $52(25,6)$ & \\
\cline { 2 - 5 } & Fakultet & $182(41,8)$ & $84(41,4)$ & 0,981 \\
\hline \multirow{2}{*}{ Obrazovanje oca } & Fakultet & $253(58,2)$ & $119(58,6)$ & \\
\cline { 2 - 5 } & Srednja škola ili niže & $254(58,9)$ & $136(69,0)$ & \\
\hline \multirow{2}{*}{$\begin{array}{l}\text { Prosjek ocjena u } \\
\text { drugoj godini }\end{array}$} & & $\mathbf{M}(\mathrm{SD})$ & $\mathbf{M}(\mathrm{SD})$ & \\
\hline \multirow{2}{*}{ Dobola ili niže } & $17,3(0,5)$ & $17,3(0,5)$ & 0,213 \\
\hline
\end{tabular}

Napomena: $\mathrm{p}=$ statistička značajnost razlike između sudionika/ca bez seksualnog iskustva i sudionika/ca sa seksualnim iskustvom $\left(\chi^{2}\right.$ test ili T-test) 


\subsection{Mjerni instrumenti}

Uporaba kondoma mjerena je jednom česticom (,Jesi li pri svojem posljednjem spolnom odnosu koristio/la kondom?"), uz mogućnost dihotomnog odgovora $(0=$ "Ne“ i $1=$ „Da“). Mjera uporabe kondoma pri posljednjem spolnom odnosu pokazala se pouzdanijom mjerom rizičnog seksualnog ponašanja od procjene učestalosti uporaba kondoma unazad određenog proteklog razdoblja (Sheeran i sur., 1999). Učestalo se upotrebljava u epidemiološki i analitički orijentiranim istraživanjima (Maticka-Tyndale i sur., 2016; Puzek i sur., 2012). Stav o uporabi kondoma mjeren je skraćenom podskalom anti-erotskih prepreka, iz Skale prepreka uporabe kondoma (Benković i sur., 2011). Skraćeni oblik skale od pet čestica korišten je u nacionalno-reprezentativnom istraživanju o reproduktivnom i seksualnom zdravlju mladih (Baćak i Štulhofer, 2012). Česticama je pridružena skala procjene od pet stupnjeva ( 1 = „Uopće se ne slažem“ do 5 $=$ „U potpunosti se slažem“). U kompozitnom obliku skale više vrijednosti ukazuju na negativniji stav o uporabi kondoma, odnosno prihvaćanje anti-erotskih prepreka uporabe. Pouzdanost navedene skale zadovoljavajuća je u obje točke mjerenja (Cronbachov $\alpha_{\mathrm{T} 4}=0,81$ i $\left.\alpha_{\mathrm{T} 6}=0,82\right)$, a vremenska stabilnost iznosi $r=0,67$. Pitanja o uporabi kondoma i stavu o uporabi kondoma bila su dostupna samo sudionicima/ama koji su naveli iskustvo seksualnog odnosa.

Učestalost uporabe pornografije mjerena je jednom česticom („U posljednjih 6 mjeseci, koliko si često koristio/la pornografiju?"), sa skalom procjene od osam stupnjeva (1 = „Nikad“ do $8=$ „Više puta dnevno“). Pitanju u upitniku bila je pridružena definicija: „U ovom upitniku, riječ pornografija odnosi se na sve materijale koji izravno i otvoreno prikazuju spolni odnos, odnosno različite seksualne aktivnosti“. $U$ četvrtom je valu istraživanja 10,5\% mladića i $60,8 \%$ djevojaka navelo da nije koristilo pornografiju u posljednjih šest mjeseci. U šestom su valu navedeni postoci iznosili 8,2\% i 58,8\%.

Traženje uzbuđenja mjereno je u četvrtom valu Kratkom skalom traženja uzbuđenja (Stephenson i sur., 2003). Skala sadrži četiri čestice (npr. „Volim raditi stvari koje su drugima zastrašujuće”) i pridruženu skalu procjene od pet stupnjeva ( $1=$ „Uopće se ne odnosi na mene" do $5=$ „U potpunosti se odnosi na mene“). Pouzdanost navedene skale iznosila je $\alpha_{T 4}=0,82(M=3,25 ; S D=0,89)$. Permisivni stavovi o seksualnosti također su mjereni u četvrtom valu pomoću četiri čestice (npr. „U kojoj mjeri smatraš prihvatljivim da spolni odnos nije vezan uz zaljubljenost i ljubav"), uz pridruženu skalu prihvaćanja od četiri stupnja (Landripet i sur., 2011). Cronbachov $\alpha$ za navedenu skalu iznosio je $0,69(\mathrm{M}=2,13 ; \mathrm{SD}=0,56)$.

\subsection{Analitička strategija}

U svrhu provjere hipoteza provedena je longitudinalna višegrupna ukrižena (engl. cross-lagged) analiza primjenom strukturalnog modeliranja. Modeli su procijenjeni metodom maksimalne vjerodostojnosti (engl. FIML - full information maximum likelihood estimation). Pristajanje modela procijenjeno je kombinacijom sljedećih pokazatelja: komparativni indeks pristajanja (engl. CFI - comparative fit index) i RMSEA (engl. 
root mean square error of approximation). Statistička usporedba pristajanja ugniježđenih modela procijenjena je $\chi^{2}$ testom. Latentne varijable u modelima identificirane su fiksiranjem zasićenja indikatora $s$ najvećim zasićenjem na 1 . Sukladno uputama (Brown, 2006), dihotomna mjera uporabe kondoma pretvorena je u latentnu varijablu u obje točke mjerenja pomoću formule $\mathrm{a}=\operatorname{var}(\mathrm{x}) \cdot(1-\mathrm{rho})$ te potom uvedena $\mathrm{u}$ strukturalni model. Testiranje invarijantnosti skale stava o uporabi kondoma provedeno je u tri koraka ( $\mathrm{Li}$ ttle, 2013).

U prvom je koraku provjerena konstruktna valjanost skale u obje vremenske točke pomoću konfirmatorne faktorske analize.

U drugom je koraku testirana mjerna invarijantnost kroz dvije vremenske točke usporedbom sljedećih međusobno ugniježđenih modela: jednakih struktura (konfiguralna invarijantnost), jednakih zasićenja (metrijska invarijantnost), jednakih zasićenja i pogrešaka (metrijska-plus invarijantnost) te jednakih zasićenja i odsječaka (skalarna invarijantnost). U trećem koraku testirana je višegrupna longitudinalna invarijantnost, također usporedbom četiriju međusobno ugniježđenih modela. Time je testirana jednakost strukture latentnih varijabli u obje točke mjerenja za djevojke i za mladiće.

Nakon testiranja invarijantnosti, odabran je model s najvišom razinom invarijantnosti, zatim su uvedene kontrolne varijable kao latentni konstrukti koji su usmjereno povezani $s$ ciljnim konstruktima u obje točke mjerenja, provjerene su mjere pristajanja te su analizirane strukturne veze između ciljnih konstrukata.

Valja uzeti u obzir da je naše uzorkovanje temeljeno na klasterima, odnosno prikupljeni su podaci ugniježđeni u razrede. Udio objašnjene varijance uporabe pornografije na razini razreda procijenjen je preko intraklasne korelacije, odnosno pomoću višerazinskog regresijskog modeliranja, posebno za svaki spol. Razinom razreda objašnjeno je $2,8 \%$ varijance uporabe pornografije kod mladića te $4,5 \%$ kod djevojaka. Zbog malog udjela objašnjene varijance razina razreda isključena je iz daljnjih analiza (Hox, 2010).

Sve su analize provedene pomoću statističkih paketa IBM SPSS v25 i R (3.5.1.).

\section{REZULTATI}

Deskriptivne informacije i koeficijenti korelacije između ključnih indikatora prikazani su u Tablici 2. Prosječne vrijednosti učestalosti uporabe pornografije ukazuju na porast učestalosti u razdoblju od 12 mjeseci kod mladića i djevojaka, ali taj porast nije statistički značajan. Prosječne vrijednosti na kompozitnoj skali stavova o kondomima također ukazuju na porast kroz vrijeme, odnosno ukazuju na razvoj negativnijeg stava. Navedena je promjena značajna i kod mladića $\left(\mathrm{t}_{(65)}=-3,12 ; \mathrm{p}=0,003\right.$; Cohenov $\left.\mathrm{d}=0,36\right)$ i djevojaka $\left(\mathrm{t}_{(151)}=-2,29 ; \mathrm{p}=0,023\right.$; Cohenov $\left.\mathrm{d}=0,20\right)$, ali uz malu do umjerenu veličinu učinka. Pad u proporciji uporabe kondoma pri posljednjem spolnom odnosu statistički je značajan samo u ženskom poduzorku $\left(\chi_{(1)}^{2}=11,80 ; \mathrm{p}<0,001\right)$. 
Tablica 2. Pearsonovi koeficijenti korelacije i deskriptivne informacije o ključnim indikatorima $(N=227)$

\begin{tabular}{|l|c|c|c|c|c|c|c|c|}
\hline & \multicolumn{5}{|c|}{ Koeficijenti korelacije } & Mladići & Djevojke \\
\cline { 2 - 10 } & 1. & 2. & 3. & 4. & 5. & 6. & M (SD) & M (SD) \\
\hline \begin{tabular}{l} 
1. Pornografija (T4) \\
\cline { 2 - 10 }
\end{tabular} & - & $0,62^{* *}$ & 0,04 & $-0,01$ & $-0,14$ & $-0,08$ & $4,90(2,07)$ & $1,92(1,52)$ \\
\hline $\begin{array}{l}\text { 2. Pornografija (T6) } \\
\text { (T4) }\end{array}$ & $0,58^{* *}$ & - & $-0,01$ & 0,05 & $-0,19^{*}$ & $-0,12$ & $5,05(2,09)$ & $2,00(1,56)$ \\
\hline $\begin{array}{l}\text { 3. Stav o kondomima } \\
\text { (T4) }\end{array}$ & 0,07 & $0,22^{*}$ & - & $0,67^{* *}$ & $-0,37^{* *}$ & $-0,33^{* *}$ & $2,91(0,93)$ & $2,46(0,93)$ \\
\hline $\begin{array}{l}\text { 4. Stav o kondomima } \\
\text { (T6) }\end{array}$ & $0,21^{*}$ & 0,05 & $0,64^{* *}$ & - & $-0,36^{* *}$ & $-0,47^{* *}$ & $2,96(0,78)$ & $2,57(0,93)$ \\
\hline $\begin{array}{l}\text { 5. Uporaba kondoma } \\
\text { (T4) }\end{array}$ & 0,00 & 0,10 & $-0,15$ & $-0,11$ & - & $0,48^{* *}$ & $48(72,7)^{\mathrm{a}}$ & $109(69,0)^{\mathrm{a}}$ \\
\hline $\begin{array}{c}\text { 6. Uporaba kondoma } \\
\text { (T6) }\end{array}$ & $0,26^{*}$ & 0,16 & $-0,14$ & $-0,34^{* *}$ & $0,43^{* *}$ & - & $46(66,7)^{\mathrm{a}}$ & $87(55,1)^{\mathrm{a}}$ \\
\hline
\end{tabular}

Napomena: Ispod dijagonale prikazani su koeficijenti korelacije u muškom, a iznad dijagonale koeficijenti u ženskom poduzorku; rezultati kompozitne mjere stava o uporabi kondoma svedeni su na originalnu skalu mjerenja; ${ }^{a}$ označava broj i postotak sudionika/ica koji su naveli uporabu kondom pri posljednjem spolnom odnosu; ${ }^{*} \mathrm{p}<0,05 ;{ }^{* *} \mathrm{p}<0,01$

U prvom koraku testiranja invarijantnosti (konfirmatorna faktorska analiza) kod čestice „Kondomi ne smanjuju seksualni užitak“ uočeno je zasićenje manje od 0,50. Čestica je izbačena iz daljnje analize (Ramey i sur., 2010; Urban i Mayerl, 2014). Preostali indikatori značajno su i pozitivno zasićeni latentnim faktorom stava prema uporabi kondoma (standardizirane procjene od 0,69 do 0,86). Latentni faktor pokazao je razmjerno visoku stabilnost $\mathrm{u}$ vremenu $(\mathrm{r}=0,76)$. Nadalje, testiranje longitudinalne invarijantnosti i višegrupne longitudinalne invarijantnosti prikazano je u Tablici 3. S obzirom na $\chi^{2}$ test razlike i indikatore pristajanja, za daljnju je analizu odabran model sa skalarnom longitudinalnom invarijantnošću i metrijskom-plus višegrupnom invarijantnošću. Drugim riječima, analize invarijantnosti pokazuju da su zasićenja i odsječci (engl. intercept) indikatora, odnosno manifestnih varijabli jednaki među vremenskim točkama te da su zasićenja i pogreške indikatora ali ne i njihovi odsječci jednaki među grupama, tj. mladićima i djevojkama. Narušena skalarna višegrupna invarijantnost znači da isti indikatori kod mladića i djevojaka različito doprinose aritmetičkoj sredini latentne varijable stava prema uporabi kondoma zbog čega nije opravdano uspoređivati aritmetičke sredine te latentne varijable među mladićima i djevojkama (za detaljnije informacije o invarijantnosti, vidjeti: Little, 2013). 
Tablica 3. Mjerna invarijantnost i višegrupna mjerna invarijantnost skale stava prema korištenju kondoma u dvije točke mjerenja $(N=227)$

\begin{tabular}{|c|c|c|c|c|c|}
\hline Invarijantnost & $\chi^{2}(\mathrm{df})$ & p & $\begin{array}{c}\text { RMSEA } \\
{[90 \% \mathrm{CI}]}\end{array}$ & CFI & $\Delta \chi^{2}(\mathrm{p})$ \\
\hline \multicolumn{6}{|c|}{ Mjerna invarijantnost skale } \\
\hline Konfiguralna & $33,19(15)$ & 0,103 & $\begin{array}{c}0,047 \\
{[0,000-0,058]}\end{array}$ & 0,994 & \\
\hline Metrijska & $24,52(18)$ & 0,139 & $\begin{array}{c}0,041 \\
{[0,000-0,077]}\end{array}$ & 0,995 & $2,31(0,507)$ \\
\hline Metrijska-plus & $25,94(22)$ & 0,254 & $\begin{array}{c}0,028 \\
{[0,000-0,066]}\end{array}$ & 0,997 & $1,41(0,841)$ \\
\hline Skalarna & $31,37(28)$ & 0,068 & $\begin{array}{c}0,047 \\
{[0,000-0,080]}\end{array}$ & 0,991 & $6,84(0,077)$ \\
\hline \multicolumn{6}{|c|}{ Mjerna višegrupna invarijantnost skale } \\
\hline Konfiguralna & $74,12(50)$ & 0,015 & $\begin{array}{c}0,066 \\
{[0,030-0,096]}\end{array}$ & 0,979 & \\
\hline Metrijska & $74,65(53)$ & 0,083 & $\begin{array}{c}0,061 \\
{[0,022-0,091]}\end{array}$ & 0,981 & $0,52(0,913)$ \\
\hline Metrijska-plus & $74,83(57)$ & 0,057 & $\begin{array}{c}0,053 \\
{[0,000-0,084]} \\
\end{array}$ & 0,985 & $0,18(0,996)$ \\
\hline Skalarna & $89,55(61)$ & 0,010 & $\begin{array}{c}0,065 \\
{[0,033-0,093]}\end{array}$ & 0,975 & $14,72(0,005)$ \\
\hline
\end{tabular}

Napomena: $\operatorname{Kod} \Delta \chi^{2}$, svaki se model uspoređuje s modelom prethodnog retka; RMSEA = root mean square error of approximation; $\mathrm{CFI}=$ comparative fit index

Uvođenjem kontrolnih varijabli (traženje uzbuđenja i permisivni stavovi o seksualnosti) izgrađen je završni strukturalni model (Slika 1; zbog preglednosti su uklonjene kontrolne varijable i pridružene im strukturne veze). Model ima dobro pristajanje $\left(\chi_{(313)}^{2}=390,988\right.$; $\mathrm{p}=0,002$; RMSEA =0,047 [0,030-0,062]; CFI=0,959). Uvidom u standardizirane koeficijente traga utvrđena je pozitivna povezanost između uporabe pornografije u T4 i stava o kondomima u T6, ali samo kod mladića $(\mathrm{r}=0,14 ; \mathrm{p}=0,003)$. Rezultat implicira da je učestalija uporaba pornografije povezana $s$ višom razinom doživljenih anti-erotskih prepreka, odnosno negativnijim stavom o uporabi kondoma 12 mjeseci kasnije. Nadalje, ni kod mladića ni djevojaka nije utvrđena značajna povezanost između učestalosti uporabe pornografije i uporabe kondoma pri posljednjem spolnom odnosu. Kod djevojaka su utvrđene dvije presječne povezanosti između stava o uporabi kondoma i stvarne uporabe kondoma $\left(\mathrm{r}_{\mathrm{T} 4}=-0,50 ; \mathrm{p}<0,001\right.$ i $\left._{\mathrm{T} 6}=-0,48 ; \mathrm{p}=0,003\right)$.

U vidu kontrolnih varijabli, kod mladića je viši stupanj permisivnih stavova značajno povezan $s$ učestalijom uporabom pornografije u prvoj točki mjerenja $\left(r_{T 4}=0,57\right.$; $\mathrm{p}=0,001)$ i s pozitivnijim stavom o kondomima u drugoj točki mjerenja $\left(\mathrm{r}_{\mathrm{T} 6}=-0,47\right.$; 
$\mathrm{p}=0,007)$. Kod djevojaka traženje uzbuđenja značajno je povezano $s$ negativnijim stavom o uporabi kondoma $\left(\mathrm{r}_{\mathrm{T} 4}=0,20 ; \mathrm{p}=0,035\right)$.

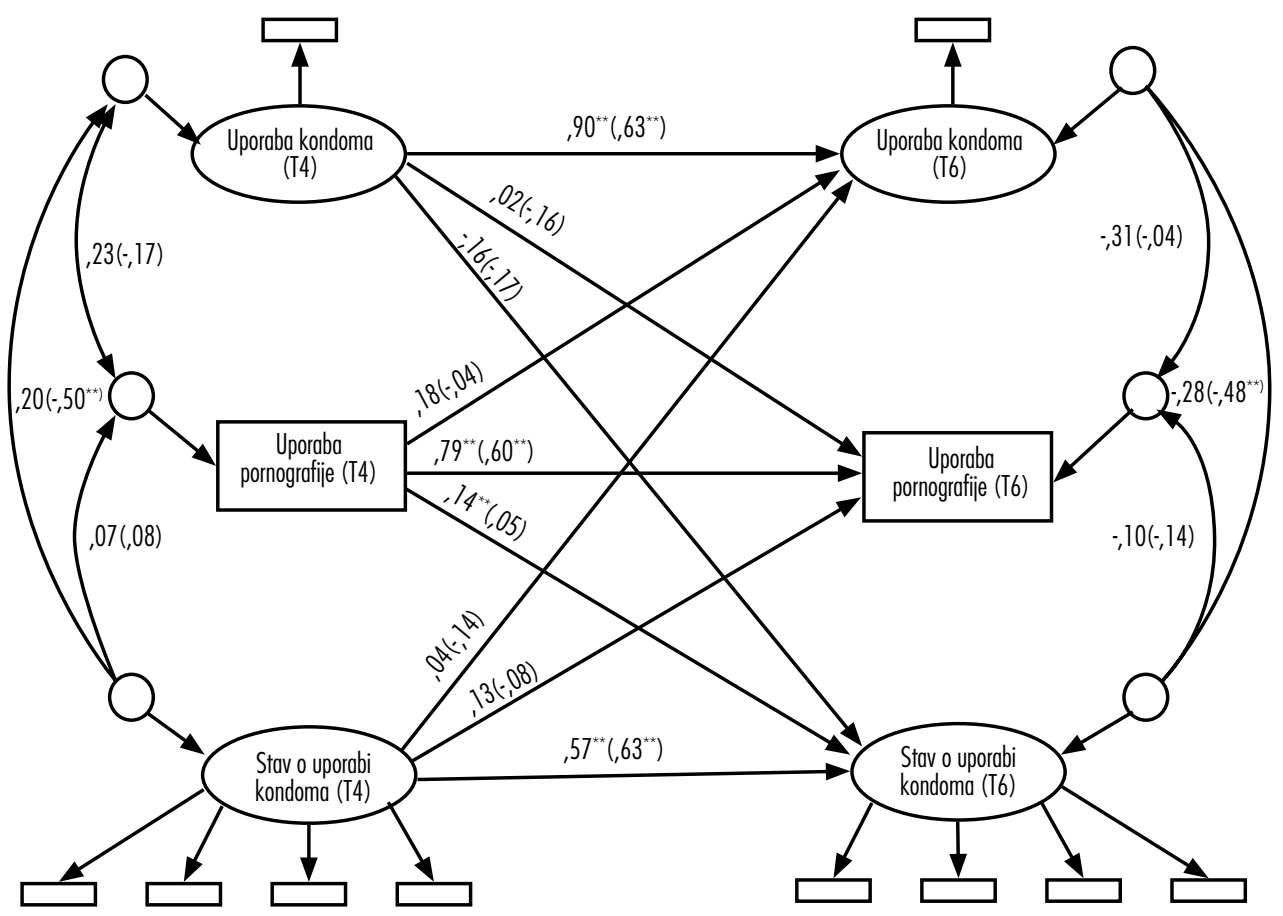

Napomena: Zbog preglednosti su uklonjene kontrolne varijable i pridružene im strukturne veze; vrijednosti van zagrade su standardizirani koeficijenti traga kod adolescenata, a unutar zagrade kod adolescentica; ${ }^{*} \mathrm{p}<0,05 ;{ }^{* *} \mathrm{p}<0,01$

Slika 1. Longitudinalni ukriženi model povezanosti izmedu uporabe pornografije, stava o uporabi kondoma i uporabe kondoma medu adolescentima $(N=227)$

\section{RASPRAVA}

Problematika moguće povezanosti pornografije i rizičnog seksualnog ponašanja, odnosno uporabe kondoma kod adolescenata tematizirana je manjim brojem uglavnom presječnih istraživanja. Osim nedostatka longitudinalnih uvida, postojeća istraživanja također nisu analizirala povezanost između uporabe pornografije i stava o uporabi kondoma, kao važnog prediktora stvarne uporabe kondoma (Sheeran i sur., 1999). Koristeći panel-uzorak adolescenata, dvije točke mjerenja te kontrolirajući traženje uzbuđenja i permisivne stavove o seksualnosti, ukriženim strukturalnim modeliranjem utvrđena je longitudinalna povezanost između učestalosti uporabe pornografije i negativnijeg stava o uporabi kondoma (H1), ali samo kod mladića. Longitudinalna povezanost između uporabe pornografije i uporabe kondoma $(\mathrm{H} 2)$ nije utvrđena ni kod mladića ni djevojaka. 
Rezultati ukazuju da je učestalija uporaba pornografije kod mladića povezana s negativnijim stavom o uporabi kondoma 12 mjeseci kasnije. Uzevši u obzir pretpostavke ${ }_{3}$ AM modela, ovaj nalaz ukazuje na potencijalnu aplikaciju seksualnih skripti na razini stava. U suvremenoj se pornografiji često prikazuje seksualni odnos kojim se ističe seksualni užitak i požuda, uz vrlo rijetko referiranje na moguće posljedice i rizike. Drugim riječima, uobičajeni pornografski prikaz spolnog odnosa često isključuje uporabu kondoma (Gorman i sur., 2010; Grudzen i sur., 2009). Konzumirajući pornografiju i aplicirajući pornografske skripte nezaštićenog spolnog odnosa, adolescenti takav oblik odnosa mogu smatrati uobičajenim ili poželjnim. Povezanost ujedno nije iznenađujuća jer je korištena mjera stava o uporabi kondoma (anti-erotske prepreke) usmjerena na izostanak aspekata užitka prilikom uporabe kondoma (fizička neugoda, nepotpun tjelesni kontakt, izostanak opuštenosti i spontanosti). Međutim, valja istaknuti da je veličina učinka navedene povezanosti vrlo mala. Nadalje, izostanak ciljne povezanosti kod djevojaka jednim je dijelom moguće objasniti rodno-specifičnim obrascima uporabe pornografije tijekom adolescencije, odnosno znatno rjeđom uporabom kod djevojaka (Doornwaard i sur., 2015), a time i rjeđom izloženošću pornografskim skriptama.

Nije utvrđena statistički značajna povezanost između uporabe pornografije i uporabe kondoma. Iako je dihotomni indikator uporabe kondoma u model uveden kao latentni konstrukt, moguće je da su izostanak značajnosti i nizak efekt učinka posljedica ograničenog varijabiliteta indikatora. Međutim, izostanak ciljne povezanosti konceptualno je sukladan rezultatima dviju presječnih istraživanja (Braun-Courville i Rojas, 2009; Lim i sur., 2017). Nizozemsko longitudinalno istraživanje također nije utvrdilo navedenu povezanost (Peter i Valkenburg, 2011a). Imajući na umu primijenjenu analitičku strategiju i pretpostavke ${ }_{3} \mathrm{AM}$ modela, nije moguće isključiti postojanje podskupine adolescenata kod kojih bi uporaba pornografije mogla potaknuti rjeđu uporabu kondoma. Primjerice, moguće je da određena kombinacija razvojnih obilježja (npr. pubertalna zrelost) i dispozicijskih obilježja (npr. impulzivnost ili seksualni interes) djeluje kao dodatni čimbenik za aktivaciju seksualnih skripti preuzetih iz pornografije. Nadalje, valja uzeti u obzir ograničeno razdoblje praćenja (12 mjeseci) u razdoblju same adolescencije. Moguće je da izloženost pornografskim seksualnim skriptama potiče rizične ponašajne ishode tek nakon duže konzumacije pornografije, odnosno da dugotrajnija uporaba postupno povećava vjerojatnost akvizicije i aplikacije skripti. Navedena je pretpostavka ujedno sukladna kultivacijskoj teoriji o medijskim učincima (Grebner i sur., 2002), prema kojoj izloženost medijskim porukama postupno mijenja (kultivira) percepciju socijalne zbilje na način na koji je prikazana u medijima. U tom kontekstu, pojedinačna izloženost ima neznatan učinak (učinak prvog reda), dok značajan učinak nastaje zbog kumulativne izloženosti (učinak drugog reda). Tome govore u prilog istraživanja koja su ukazala na povezanost između uporabe pornografije i nekorištenja kondoma u post-adolescenciji (Lin i sur., 2020; Wright i sur., 2016) i među odraslima (Peter i Valkenburg, 2011a). 


\subsection{Implikacije}

Imajući na umu da istraživanja o zdravstvenim navikama mladih sustavno ukazuju da 20-30\% mladića nikada ili rijetko koristi kondom (Hođić i Bijelić, 2003; Kuzman i sur., 2008; Pavić Šimetin i sur., 2016), javno-zdravstveni imperativ je identificirati rizične čimbenike koji doprinose neuporabi kondoma. Ako pornografija, koju većina mladića koristi u većoj mjeri nego djevojke, pokazuje potencijal za formiranje negativnijeg stava o uporabi kondoma, a time oslabljuje namjeru stvarne uporabe (Albarracín i sur., 2001; Teye-Kwadjo i sur., 2017), potrebno ju je sagledati kao jednu od mogućih rizičnih čimbenika za zdravlje adolescenata. Osim toga, pornografija može biti rizičan čimbenik za druge aspekte psihosocijalne i seksualne dobrobiti adolescenata, poput razvijanja negativnijih stavova o vlastitom tjelesnom izgledu, seksualnoj nesigurnosti i rodnoj stereotipizaciji (Koletić, 2017; Peter i Valkenburg, 2016).

Kako bi se umanjila potencijalna štetnost uporabe pornografije, jedan od mogućih preventivnih i / ili zaštitničkih pristupa razvoj je i implementacija programa medijske pismenosti za adolescente, ali i njihove roditelje. Važna komponenta takvog programa jest razvijanje sposobnosti kritičnog čitanja pornografskih prikaza seksualnog čina, užitka i rizika. Nedavna evaluacijska istraživanja ukazuju na pozitivan učinak glede, primjerice, smanjenje percepcije pornografije kao kvalitetnog izvora informacija o seksualnosti (Rothman i sur., 2018). Sadržaj i kvaliteta takvih programa uvelike ovisi o daljnjim istraživačkim naporima usmjerenima na razumijevanje i sistematizaciju mogućih rizičnih ishoda učestalije uporabe pornografije u adolescenciji.

\subsection{Ograničenja istraživanja i preporuke za buduća istraživanja}

U nastavku su navedena ograničenja istraživanja koje valja imati na umu prilikom interpretacije prikazanih rezultata. Prvo, učestalost uporabe pornografije i uporabe kondoma mjereni su jednom česticom, čime je onemogućena provjera metrijskih karakteristika. Međutim, jednočestični indikatori podjednako su prihvatljivi kao i višečestični, ali u slučajevima kada su mjereni konstrukti lako zamislivi (npr. određena ponašanja) te kada sudionici/e dijele ujednačeno razumijevanje mjerenog konstrukta (Bergkvist i Rossiter, 2007; Diamantopoulos i sur., 2012). Drugo, stav o uporabi kondoma mjeren je pomoću jedne dimenzije, odnosno anti-erotskih prepreka. Buduća bi istraživanja trebala uključiti i druge dimenzije uporabe kondoma, poput prepreka vezanih uz pregovaranje o uporabi kondoma, prepreka vezanih uz društvene norme, kupnju kondoma i slično (Benković i sur., 2011). Treće, dobiveni su rezultati reprezentativniji za adolescente/ice i učenike/ce boljeg školskog uspjeha zbog osipanja sudionika/ca tijekom trajanja istraživanja. Četvrto, analize su temeljene na dvije točke mjerenja koje obuhvaćaju razdoblje od 12 mjeseci. U ovom istraživanju nije bilo moguće adekvatno analizirati medijacijsku ulogu stava o uporabi kondoma u odnosu između učestalosti uporabe pornografije i stvarne uporabe kondoma jer su oba konstrukta mjerena samo u dvije točke. S obzirom na to da je u nedavnim istraživanjima istaknuta važnost provjere medijacijskih modela koju obuhvaćaju uporabu pornografije i stavove (npr. per- 
misivne stavove o seksualnosti), buduća bi istraživanja trebala koristiti minimalno tri točke mjerenja (Braithwaite i sur., 2015; Wright, 2018). Drugim riječima, više točaka mjerenja, a time i duže razdoblje promatranja, omogućilo bi robusniju analizu longitudinalne povezanosti, kao i provjeru analitički složenijeg odnosa između ciljnih konstrukata. Konačno, nalazi ovog analitički usmjerenog istraživanja ne mogu se poopćiti na populaciju hrvatskih srednjoškolaca/ki zbog neprobabilističkog tipa uzorkovanja u jednom gradu.

Stav o uporabi kondoma, kao i samo odluka o uporabi kondoma, formiraju se kroz komunikaciju između partnera i partnerice te u tom kontekstu partneri mogu imati veći utjecaj na odluke o korištenju kontracepcije (Vasilenko i sur., 2015). Prema tome, buduća bi istraživanja trebala uključiti analize dijada kako bi se rasvijetlila dinamika odlučivanja, uz kontroliranje doprinosa učestalosti uporabe pornografije.

\section{ZAKLJUČAK}

Prema dosadašnjim istraživanjima, stav o uporabi kondoma važan je prediktor stvarne uporabe kondoma. Međutim, razmjerno je malo istraživanja analiziralo povezanost između uporabe pornografije, stava o uporabi kondoma i stvarne uporabe kondoma među adolescentima. Koristeći panel-uzorak adolescenata i dvije točke mjerenja, cilj ovog istraživanja bio je analizirati longitudinalnu povezanost između učestalosti uporabe pornografije te stava o uporabi kondoma i uporabe kondoma pri posljednjem spolnom odnosu. Utvrđena je slaba povezanost između učestalije uporabe pornografije u početnoj točki mjerenja i negativnijeg stava o uporabi kondoma 12 mjeseci poslije, ali samo među mladićima. Nije utvrđena longitudinalna povezanost između uporabe pornografije i uporabe kondoma.

\section{LITERATURA}

Albarracín, D., Johnson, B. T., Fishbein, M. i Muellerleile, P. A. (2001). Theories of Reasoned Action and Planned Behavior as Models of Condom Use: A Meta-Analysis. Psychological Bulletin, 127(1): 142-161.

Ashenhurst, J. R., Wilhite, E. R., Harden, K. P. i Fromme, K. (2017). Number of Sexual Partners and Relationship Status are Associated with Unprotected Sex Across Emerging Adulthood. Archives of Sexual Behavior, 46(2): 419-432.

Baams, L., Overbeek, G., Dubas, J. S., Doornwaard, S. M., Rommes, E. i van Aken, M. A. G. (2014). Perceived Realism Moderates the Relation Between Sexualized Media Consumption and Permissive Sexual Attitudes in Dutch Adolescents. Archives of Sexual Behavior, 44(3): 743-754.

Baćak, V. i Štulhofer, A. (2012). Condom Use Errors and Problems in a National Sample of Young Croatian Adults. Archives of Sexual Behavior, 41(4): 995-1003. 
Benković, V., Štulhofer, A. i Baćak, V. (2011). Konstrukcija i evaluacija višedimenzionalnog instrumenta za procjenu zapreka uporabi kondoma. Društvena istraživanja, 20(3): 751-770.

Bergkvist, L. i Rossiter, J. R. (2007). The Predictive Validity of Multiple-Item Versus Single-Item Measures of the Same Constructs. Journal of Marketing Research, 44(2): 175-184.

Braithwaite, S. R., Coulson, G., Keddington, K. i Fincham, F. D. (2015). The Influence of Pornography on Sexual Scripts and Hooking Up Among Emerging Adults in College. Archives of Sexual Behavior, 44: 111-123.

Braun-Courville, D. K. i Rojas, M. (2009). Exposure to Sexually Explicit Web Sites and Adolescent Sexual Attitudes and Behaviors. Journal of Adolescent Health, 45(2): 156-162.

Brown, T. A. (2006). Confirmatory Factor Analysis for Applied Research. New York, NY: The Guilford Press.

Carrol, E. N., Zuckerman, M. i Vogel, W. H. (1982). A Test of the Optimal Level of Arousal Theory of Sensation Seeking. Journal of Personality and Social Psychology, 42(3): 572-575.

Centers for Disease Control and Prevention. (2017). Sexually Transmitted Disease Surveillance 2016. Washington, D.C.: U. S. Department of Health and Human Services.

Chen, H., Cohen, P. i Chen, S. (2010). How Big is a Big Odds Ratio? Interpreting the Magnitudes of Odds Ratios in Epidemiological Studies. Communications in Statistics: Simulation and Computation, 39(4): 860-864.

Diamantopoulos, A., Sarstedt, M., Fuchs, C., Wilczynski, P. i Kaiser, S. (2012). Guidelines for Choosing Between Multi-Item and Single-Item Scales for Construct Measurement: A Predictive Validity Perspective. Journal of the Academy of Marketing Science, 40(3): 434-449.

Doornwaard, S. M., van den Eijnden, R. J. J. M., Overbeek, G. i Ter Bogt, T. F. M. (2015). Differential Developmental Profiles of Adolescents Using Sexually Explicit Internet Material. Journal of Sex Research, 52(3): 269-281.

Fergus, S., Zimmerman, M. A. i Caldwell, C. H. (2007). Growth Trajectories of Sexual Risk Behavior in Adolescence and Young Adulthood. American Journal of Public Health, 97(6): 1096-1101.

Fortenberry, J. D. (2016). Adolescent Sexual Well-Being in the 21st Century. Journal of Adolescent Health, 58(1): 1-2.

Gagnon, J. H. i Simon, W. (2005). Sexual Conduct: The Social Sources of Human Sexuality. New Brunswick, NJ: AldineTransaction.

Gorman, S., Monk-Turner, E. i Fish, J. N. (2010). Free Adult Internet Web Sites: How Prevalent are Degrading Acts? Gender Issues, 27(3-4): 131-145.

Grebner, G., Gross, L., Morgan, M., Signorielli, N. i Shanahan, J. (2002). Growing Up with Television: Cultivation Processes. U: Bryant, J. i Zillmann, D. (ur.), LEA's Communication Series. Media Effects: Advances in Theory and Research (str. 43-67). Mahwah, NJ: Lawrence Erlbaum Associates Publishers. 
Grudzen, C. R., Elliott, M. N., Kerndt, P. R., Schuster, M. A., Brook, R. H. i Gelberg, L. (2009). Condom Use and High-Risk Sexual Acts in Adult Films: A Comparison of Heterosexual and Homosexual Films. American Journal of Public Health, 99: 152-156.

Hođić, A. i Bijelić, N. (2003). Značaj roda u stavovima i seksualnom ponašanju adolescenata $i$ adolescentica. Zagreb: CESI.

Hox, J. J. (2010). Multilevel Analysis: Techniques and Applications. New York, NY: Routledge.

Koletić, G. (2017). Longitudinal Associations Between the Use of Sexually Explicit Material and Adolescents' Attitudes and Behaviors: A Narrative Review of Studies. Journal of Adolescence, 57: 119-133.

Kuzman, M., Pejnović Franelić, I. i Pavić Šimetin, I. (2008). Ponašanje u vezi sa zdravljem u djece školske dobi 2005/2006. Zagreb: Hrvatski zavod za javno zdravstvo.

Landripet, I., Štulhofer, A. i Baćak, V. (2011). Changes in Human Immunodeficiency Virus and Sexually Transmitted Infections-Related Sexual Risk Taking Among Young Croatian Adults: Findings from the 2005 and 2010 Population-Based Surveys. Croatian Medical Journal, 52(4): 458-468.

Leonhardt, N. D. i Willoughby, B. J. (2018). Longitudinal Links Between Pornography Use, Marital Importance, and Permissive Sexuality During Emerging Adulthood. Marriage \& Family Review, 54(1): 64-84.

Lim, M. S. C., Agius, P. A., Carrotte, E. R., Vella, A. M. i Hellard, M. E. (2017). Young Australians' Use of Pornography and Associations with Sexual Risk Behaviours. Australian and New Zealand Journal of Public Health, 41(4): 438-443.

Lin, W.-H., Liu, C.-H., i Yi, C.-C. (2020). Exposure to Sexually Explicit Media in Early Adolescence is Related to Risky Sexual Behavior in Emerging Adulthood. PLOS ONE, 15(4): 1-26. DOI: 10.1371/journal.pone.0230242

Little, T. D. (2013). Longitudinal Structural Equation Modeling. New York, NY: Guilford Press.

Luder, M.-T., Pittet, I., Berchtold, A., Akré, C., Michaud, P.-A. i Surís, J.-C. (2011). Associations Between Online Pornography and Sexual Behavior Among Adolescents: Myth or Reality? Archives of Sexual Behavior, 40(5): 1027-1035.

Maticka-Tyndale, E., Kerr, J., Mihan, R. i Mungwete, R. (2016). Condom Use at Most Recent Intercourse Among African, Caribbean, and Black Youth in Windsor, Ontario. International Journal of Sexual Health, 28(3): 228-242.

Mokdad, A. H., Forouzanfar, M. H., Daoud, F., Mokdad, A. A., El Bcheraoui, C., Moradi-Lakeh, M., Kyu, H. H., Barber, R. M., Wagner, J., Cercy, K., Kravitz, H., Coggeshall, M., Chew, A., O’Rourke, K. F., Steiner, C., Tuffaha, M., Charara, R., Al-Ghamdi, E. A., Adi, Y., Afifi, R. A., Alahmadi, H., AlBuhairan, F., Allen, N., AlMazroa, M., Al-Nehmi, A. A., AlRayess, Z., Arora, M., Azzopardi, P., Barroso, C., Basulaiman, M., Bhutta, Z. A.; Bonell, C., Breinbauer, C., Degenhardt, L., Denno, D., Fang, J., Fatusi, A., Feigl, A. B., Kakuma, R., Karam, N., Kennedy, E., Khoja, T. A. M., Maalouf, F., Obermeyer, C. M., Mattoo, A., McGovern, T., 
Memish, Z. A., Mensah, G. A., Patel, V., Petroni, S., Reavley, N., Zertuche, D. R., Saeedi, M., Santelli, J., Sawyer, S. M., Ssewamala, F., Taiwo, K., Tantawy, M., Viner, R. M., Waldfogel, J., Zuñiga, M. P., Naghavi, M., Wang, H., Vos, T., Lopez, A. D., Al Rabeeah, A. A., Patton, G. C. i Murray, C. J. L. (2016). Global Burden of Diseases, Injuries, and Risk Factors for Young People's Health During 1990-2013: A Systematic Analysis for the Global Burden of Disease Study 2013. The Lancet, 387(10036): 2383-2401.

Palmer, M. J., Clarke, L., Ploubidis, G. B., Mercer, C. H., Gibson, L. J., Johnson, A. M., Copas, A. J. i Wellings, K. (2017). Is "Sexual Competence” at First Heterosexual Intercourse Associated With Subsequent Sexual Health Status? The Journal of Sex Research, 54(1): 91-104.

Pavić Šimetin, I., Mayer, D., Musić Milanović, S., Pejnović Franelić, I. i Jovičić, D. (2016). Istraživanje o zdravstvenom ponašanju učenika. Zagreb: Hrvatski zavod za javno zdravstvo.

Peter, J. i Valkenburg, P. M. (2010). Processes Underlying the Effects of Adolescents' Use of Sexually Explicit Internet Material: The Role of Perceived Realism. Communication Research, 37(3): 375-399.

Peter, J. i Valkenburg, P. M. (2011a). The Influence of Sexually Explicit Internet Material on Sexual Risk Behavior: A Comparison of Adolescents and Adults. Journal of Health Communication, 16(7): 750-765.

Peter, J. i Valkenburg, P. M. (2011b). The Use of Sexually Explicit Internet Material and Its Antecedents: A Longitudinal Comparison of Adolescents and Adults. Archives of Sexual Behavior, 40(5): 1015-1025.

Peter, J. i Valkenburg, P. M. (2016). Adolescents and Pornography: A Review of 20 Years of Research. Journal of Sex Research, 53(4-5): 509-531.

Petley, J. (2014). The Regulation of Pornography on Video-On-Demand in the United Kingdom. Porn Studies, 1(3): 260-284.

Puzek, I., Štulhofer, A. i Božičević, I. (2012). Is Religiosity a Barrier to Sexual and Reproductive Health? Results from a Population-Based Study of Young Croatian Adults. Archives of Sexual Behavior, 41(6): 1497-1505.

Quadara, A., El-Murr, A. i Latham, J. (2017). The Effects of Pornography on Children and Young People: An Evidence Scan. Melbourne: Australian Institute of Family Studies. Ramey, H. L., Busseri, M. A., Khanna, N., Hamilton, Y. N., Ottawa, Y. N. i Rose-Krasnor, L. (2010). Youth Engagement and Suicide Risk: Testing a Mediated Model in a Canadian Community Sample. Journal of Youth and Adolescence, 39(3): 243-258.

Rothman, E. F., Adhia, A., Christensen, T. T., Paruk, J., Alder, J. i Daley, N. (2018). A Pornography Literacy Class for Youth: Results of a Feasibility and Efficacy Pilot Study. American Journal of Sexuality Education, 13(1): 1-17. DOI: 10.1080/15546128.2018.1437100

Sheeran, P., Abraham, C. i Orbell, S. (1999). Psychosocial Correlates of Heterosexual Condom Use: A Meta-Analysis. Psychological Bulletin, 125(1): 90-132. 
Stephenson, M. T., Hoyle, R. H., Palmgreen, P. i Slater, M. D. (2003). Brief Measures of Sensation Seeking for Screening and Large-Scale Surveys. Drug and Alcohol Dependence, 72(3): 279-286.

Štulhofer, A., Graham, C., Božičević, I., Kufrin, K. i Ajduković, D. (2009). An Assessment of HIV/STI Vulnerability and Related Sexual Risk-Taking in a Nationally Representative Sample of Young Croatian Adults. Archives of Sexual Behavior, 38(2): 209-225.

Štulhofer, A. i Rimac, I. (2009). Determinants of Homonegativity in Europe. Journal of Sex Research, 46(1): 24-32.

Tarrant, S. (2015). Pornography and Pedagogy: Teaching Media Literacy. U: Comella, L. i Tarrant, S. (ur.), New Views on Pornography: Sexuality, Politics and the Law (str. 417-430). Westport, CT: Praeger.

Teye-Kwadjo, E., Kagee, A. i Swart, H. (2017). Predicting the Intention to Use Condoms and Actual Condom Use Behaviour: A Three-Wave Longitudinal Study in Ghana. Applied Psychology: Health and Well-Being, 9(1): 81-105.

Urban, D. i Mayerl, J. (2014). Strukturgleichungsmodellierung. Ein Ratgeber für die Praxis. Herausgeber: Springer.

Vasilenko, S. A., Kreager, D. A. i Lefkowitz, E. S. (2015). Gender, Contraceptive Attitudes, and Condom Use in Adolescent Romantic Relationships: A Dyadic Approach. Journal of Research on Adolescence, 25(1): 51-62.

Warner, T. D. (2018). Adolescent Sexual Risk Taking: The Distribution of Youth Behaviors and Perceived Peer Attitudes Across Neighborhood Contexts. Journal of Adolescent Health, 62(2): 226-233.

Wingood, G. M., DiClemente, R. J., Harrington, K., Davies, S., Hook, E. W. i Oh, M. K. (2001). Exposure to X-Rated Movies and Adolescents' Sexual and Contraceptive-Related Attitudes and Behaviors. Pediatrics, 107(5): 1116-1119.

Wright, P. J. (2011). Mass Media Effects on Youth Sexual Behavior Assessing the Claim for Causality. Annals of the International Communication Association, 35(1): 343385.

Wright, P. J. (2014). Pornography and the Sexual Socialization of Children: Current Knowledge and a Theoretical Future. Journal of Children and Media, 8(3): 305-312.

Wright, P. J. (2018). Pornography and Sexual Behavior: Do Sexual Attitudes Mediate or Confound? Communication Research, 47(3): 451-475.

Wright, P. J., Tokunaga, R. S. i Kraus, A. (2016). Consumption of Pornography, Perceived Peer Norms, and Condomless Sex. Health Communication, 31(8): 954-963.

Zimmer-Gembeck, M. J. i Helfand, M. (2008). Ten Years of Longitudinal Research on U.S. Adolescent Sexual Behavior: Developmental Correlates of Sexual Intercourse, and the Importance of Age, Gender and Ethnic Background. Developmental Review, 28(2): 153-224. 


\title{
PORNOGRAPHY, ATTITUDES TOWARD CONDOM USE AND CONDOM USE AMONG THE ADOLESCENTS IN THE CITY OF RIJEKA
}

\author{
Goran Koletić and Jasmina Mehulić
}

\begin{abstract}
Easily available online pornography prompted concerns among educational experts and the general public about its adverse effects on adolescent psychosocial and sexual development. This study focuses on potential links between pornography use and risky sexual behavior, particularly unprotected sexual intercourse. According to existing research, attitudes toward condom use posit an important predictor of actual condom use. However, relatively few studies have investigated these two pornography-related associations. Informed by the recently developed Acquisition, Activation, Application Model (AM), this study explores whether adolescents' use of pornography predicts attitudes toward condom use and actual condom use. Classroom-based data collection was conducted in the period between 2015 and 2018 among high-school sophomores in 14 schools in the city of Rijeka $\left(N=227 ; M_{\text {age }}=17.3 ; S D=0.5\right)$. Cross-lagged multigroup structural equation modeling with two measurement points was used to assess target associations, controlling for sensation seeking and permissive sexual attitudes. The results reveal that the baseline frequency of pornography use is related to attitudes toward condom use, but only among male adolescents. Nonsignificant associations between pornography use and condom non-use were found for both genders. Recommendations for future research and practical implications of this study are also discussed. Our findings could be useful for experts in education, media literacy, and public health experts, as well as for the general public.
\end{abstract}

Key words: pornography, attitudes toward condoms, condom use, adolescents, longitudinal assessment, structural equation modeling

\section{PORNOGRAPHIE, ANWENDUNG VON KONDOMEN UND STELLUNGNAHME DAZU BEI HERANWACHSENDEN IN RIJEKA}

\author{
Goran Koletić und Jasmina Mehulić
}

\section{Zusammenfassung}

Die Einfachheit des Zugangs zur Pornographie im Internet hat wegen negativer Auswirkungen der Pornographie auf psychosoziale und sexuelle Reifung von Adoleszenten viel Besorgnis, sowohl der Erziehungsfachleute als auch der Allgemeinheit, erregt. Die angenommene Verbindung zwischen Nutzung von Pornographie und riskantem Sexualverhalten, insbesondere ungeschütztem Geschlechtsverkehr, steht oft im Fokus der Aufmerksamkeit. Der bisherigen Forschung zufolge ist die Stellungnahme zur Anwendung von Kondomen ein wichtiger Prädiktor für tatsächliche Anwendung davon. Verhältnismäßig wenige Studien haben jedoch die Verbindung von Nutzung der Pornographie, Stellungnahme zur Anwendung von Kondomen und Anwendung von Kondomen unter Adoleszenten analysiert. Der Konzeptrahmen dieser Studie besteht aus dem unlängst entwickelten Modell der Akquisition, Aktivierung und Anwendung (AM). Das Ziel dieser Studie ist eine Analyse der longitudinalen Verbindung zwischen der Frequenz der Nutzung von Pornographie und der Stellungnahme zur Anwendung von Kondomen und der Kondomanwendung beim letzten Sexualverkehr. Die Angaben wurden in zwei Wellen in einer Umfrage unter den Schülern / Schülerinnen aus 14 Mittelschulen in Rijeka vom 2015 bis 2018 ( $\left.N=227 ; M_{\text {Alter }}=17,3 ; S D=0,5\right)$ gesammelt. Eine Mehrgruppen-Längsschnitt-Analyse unter Anwendung der Strukturmodellierung mit zwei Messpunkten wurde angwandt, um die Suche nach Erregung und freizügige Einstellung zum Sex zu bewerten. Es wurde eine Längsschnittbeziehung zwischen der Nutzungsfrequenz der Pornographie und einer negativen Einstellung zur Anwendung von Kondomen festgestellt, aber nur bei Jungen. Es wurde keine Längsschni- 
ttbeziehung zwischen der Nutzung der Pornographie und Anwendung der Kondome festgestellt. Ergebnisse und Empfehlungen für weitere Forschung und praktische Implikationen werden diskutiert. Die Resultate können Fachkräften aus den Bereichen Bildung, Medienkompetenz und Gesundheitswesen, aber auch der Allgemeinheit dienen.

Schlüsselwörter: Pornographie, Stellungnahme zur Anwendung von Kondomen, Anwendung von Kondomen, Adoleszenten, Longitudinalstudie, Strukturmodellierung 